\title{
The Benefits and Challenges of IFRS Adoption in India: The Dawn of a New Era
}

\author{
Anubha Srivastava (Corresponding author) \\ Consultant of Accounting and Finance, Djerapah Megah Plasindho \\ Sukoharjo and Visiting faculty, UNDIP University Semarang, Indonesia
}

Tel: 62-8572-1263-938Ｅmail: anusri2799@gmail.com

Preeti Kulshrestha

Professor of Accounting, Dilla University, Ethiopia

Tel: 91-9557-088-643

Received: November 7, 2019 Accepted: December 5, 2019 Published: December 9, 2019

doi:10.5296/ijafr.v9i4.16012 URL: https://doi.org/10.5296/ijafr.v9i4. 16012

\begin{abstract}
We endeavor to examine the benefits and the key challenges associated to International financial reporting standards enforcement in India in the current paper. The research is founded on structured questionnaire survey of 150 accounting professionals and applied purposive sampling technique to assemble the data from target respondents from various business sectors of India. The data from secondary sources, conducted through personalized interview, has been examined qualitatively with respect to IFRS convergence. The research outcome contributes to the existing literature stating that the respondents are optimistic about the benefits related to IFRS adoption but the challenges are too a major roadblock. Since the enforcement of IFRS has already initiated in India thus it is imperative to comprehend the benefits and cost associated with IFRS in Indian context. This study results recognizes that though convergence process with IFRS will pose few key challenges but the overall benefit will overweigh the challenges. This study recommends that IFRS training seminars and workshops at massive scale should be embarked upon by regulatory bodies, professional organizations like ICAI, KPMGs and other training institutions to provide for a smooth transition from local standards to IFRS.
\end{abstract}

Keywords: IFRS, IFRS adoption, Benefits of IFRS, Key challenges of IFRS, India 


\section{Introduction}

This rapid change in the financial reporting world is demanding enforcement of international financial reporting standard (IFRS) with a purpose to promote more consistency, credibility, relevance of accounting information and the globalization of economies. The financial reporting system of business activities has undergone a tremendous transformation over the last couple of decades. According to Whittington (2008), the convergence of the accounting standards started in the early 2001 with the objective of bringing transparency and harmonization of the standards. The differences in the compliance are rooted in the different market environmental factors and structures of corporate governance in which IFRS is implemented. According to Nobes, (2004) and Hoyle, et al., (2009), such revolutions encourage for the adoption and adaptation of local accounting rules with International Financial Reporting Standards (IFRS) formerly International Accounting Standards (IAS). Lenormand \&Touchais (2009) and Barth et al. (2008) stated that many researchers believe that the adoption of International Financial Reporting Standards (IFRSs) increases the quality of financial statement. Iatridis (2010), Paglietti (2009), Pannanen and Lin (2009) indicated in their research that studies conducted in the past in several countries like Britain, Italy, and Germany, etc, revealed that the implementation of IFRS has improved the quality of accounting information. India set a roadmap for IFRS converged Ind-AS which was initially set to be obligatory for listed, public interest entities and large-sized organizations with effect from 1st April 2011. However, despite the excellent budge and hint towards full IFRS convergence in India with effect from 1st April 2011. The move proved futile (ICAI, 2012). Albeit the setbacks, Indian Government insisted and proved its unrelenting commitment towards convergence, thus another adoption date has recently been officially announced (Notification No G.S.R, dated, 16th February 2015). On $2^{\text {nd }}$ January 2015, the Ministry of Corporate Affairs issued a note highlighting various phrases in which Indian accounting standards converged with IFRS are proposed to be implemented in India for companies other than Insurance companies, Banking companies, and NBFCs. The application of Ind AS is totally based on the net worth and listing status of the company.

1. Accounting periods beginning on $1 / 04 / 15$ or with the comparatives for the period ending on 31/03/15 or thereafter - Voluntary Adoption (Condition: Once a company adopts IAS, it cannot switch back)

2. Accounting periods beginning on $1 / 04 / 16$ or with the comparatives for the period ending on 31/03/15 or thereafter- Mandatory Adoption

- Companies whose equity or debt securities are listed or are in the process of being listed on any stock exchange in India or outside India and having a net worth of 500 Crore or above.

3. Accounting periods beginning on $1 / 04 / 17$ or with the comparatives for the period ending on 31/03/1 or thereafter- Mandatory Adoption

- Companies whose equity and/or debt securities are listed or are in the process of being listed on any stock exchange in India or outside India and having a net worth of less than 
rupees 500 Crore. Unlisted companies whose net worth is more than 250 Crore INR but less than 500 Crore INR.

Source: Indian GAPP, IFRS, and Ind. AS, Deloitte Report 2015

Enforcement of IFRS will contribute towards the flow of global investment in both developed and developing economies and will improve the ability of investors to compare investment options on a global basis, thereby reducing the risk of errors of judgment. Irvine and Lucas, (2006) in their research indicated that there is a requirement to examine challenges encountered in actually implementing IFRS in developing economies. Thus this study aims to examine not only benefits but key challenges too regarding IFRS convergence mechanism in India. In addition, this research also aims to test statistically the difference in respondent's perception based on their professional affiliation and roles with respect to IFRS adoption's benefits and challenges.

\section{Literature Review}

\subsection{Theoretical Background of IFRS}

The main purpose of IASB is to ensure that financial reporting is relevant, transparent, reliable and understandable in order to enable users and prepares to make a logical decision. This can be done by eliminating the differences in accounting policies and principles between countries. IFRS are set of high-quality accounting standards issued by the International Accounting Standards Board (IASB) which is expected to bring harmonization of the preparation of financial statement between countries. Penman (1984) indicated that financial reports can be useful if they represent the 'economic substance' of an organization in terms of relevance, reliability, comparability and aids interpretation. According to Latifah et al., (2012) IFRS are a manifestation of globalization, with financial reports prepared under IFRS presenting an image consistent with that of multinational corporations and developed nations. Recently, it is over 115 countries around the world require or permit IFRS, including big countries such as the EU, China, Japan, South Korea, Australia, Russia, etc. United States who adopt US GAAP for years also accept IFRS. Epstein and Adam (2009) stated that IFRS adoption is believed to enhance greater transparency and disclosures in financial statements. (Quigley (2007) stated that accounting information should be harmonized for there to be capital market globalization. Zeghal and Mhedhbi, (2006), Hassan et al., (2009) and Gyasi (2010) concluded that harmonization of accounting information across the globe will benefit developing countries because it provides them with a clear accounting framework and principles. According to Faraj and Akbar (2010), the adoption of IFRS by the developing countries is not only necessary, but also required to access the capital markets at the global level. Choi, F., and R. Levich, (1991) stated in his paper that as a result of the increasing popularity of investing in the global economy investors are becoming insanely interested in emerging markets as they present a diversification opportunity. According to Nwabueze and Ezeani \& Oladele (2012), the research into the financial regulatory bodies has been scanty over the period of time. 


\subsection{Benefits of IFRS}

In opinion of Madawaki (2012), Nigeria adopted IFRS in order to reap benefits like foreign direct investments, easy access to external capital for local companies, Reduction in the cost of doing business by elimination of the requirement of supplementary information from Nigerian companies, ease in consolidation of financial information of same company with its offices in different countries, enhanced quality of financial information for stakeholders and supervisory authorities. According to Arum Puspa (2013), adoption of IFRS will reduce the regulatory gaps and enhance the quality as well as the credibility of the financial statements of business entities across the world. With the adoption of IFRS, financial reporting quality is expected to become more relevant and reliable. In the opinion of Rao (2013), IFRS adoption is a right step in the right direction. Though the implementation of IFRS is facing issues and challenges, however, the benefits outweigh the challenges. The adoption of IFRS will allow Indian companies to produce more credible financial statements which will not only be uniform but will also provide a basis for better interpretation. According to Miazee (2014), in a developing country like Bangladesh, it is high time to implement the adopted IFRS more accurately with all the resources that it has. However, only ICAB cannot handle this action. In the opinion of Enahoro and Ocansey (2014), the adoption of IFRS demands a new set of skills and expertise but at the same time challenges such as inconsistencies in applicable laws, emerging technical areas and cost versus benefit analysis are more evident in developing countries like Ghana and Nigeria. According to Vinayaga and Moorthy (2014), adoption of IFRS will create opportunities such as Presentation of financial statement on a single set of global standards, Enhanced quality, transparency and comparability of financial statements which would be based on modern accounting principles and concepts which are being applied in global markets, Benefit of raising capital from abroad, Improvement in cross border investment by enhancing the comparability of financial statements prepared in any part of the world. According to Forsberg \& Ojala, (2014), adoption of IFRS has improved the accounting quality of China which has resulted in an increase in the level of foreign direct investment which has further contributed towards the economic growth of China. According to Naghshbandi \& Ombati (2016), in comparison to local accounting standards, IFRS is perceived as a high-quality accounting standard as it enriches the comparability of financial statements by investors. The motivational factors for adoption of IFRS are Globalization, the attraction of foreign direct investments. In the opinion of Ratheesh (2015), IFRS will enable Indian companies to standardize their performance with global counterparts. Early adoption of IFRS provides an opportunity for companies to foresee challenges, manage outcomes and apply the best solutions. Companies are required to conduct a diagnostic study before moving forward for a full IFRS conversion. According to Venkatesh \& Venkateswarlu (2016), adoption of IFRS will create opportunities like better access to global markets, enhanced quality of financial reporting, encouragement of international investment. However, the challenges faced with the adoption of IFRS are taxation, change in the information system. According to Aggarwal (2016) the convergence to a single set of globally accepted standards is in the best interest of the stakeholders, contributing to the efficient flow of capital within countries and across borders. But at the same time, the requirement of changes to be 
introduced in the laws and regulations and lack of adequate professionals are some of the hindrances in the convergence process.

\subsection{Challenges of IFRS}

Though the enforcement of IFRS is recommended by many researchers but the implementation of IFRS in many countries poses challenges too. IFRS convergence mechanism will bring few inherent challenges \& issues like lack of required software, lack of human capital training, the huge cost involved in implementation and modification in rules and regulations, etc. Jermakowicz and Gornik-Tomaszewski, (2006), Jones and Higgins, (2006), Weaver and Woods, (2015) and Ocheni (2015) stated that the past decade witnessed sporadic efforts to recognize the challenges of implementation of IFRS with respect to communication, translation and interpretation of standards from the IASB, and to comprehend the challenges tackled by users and practitioners, with respect to education, staffing, cost, training and IT infrastructure According to Islam and Bhattacharjee (2009), the adoption of IFRS in Bangladesh is expected to reduce information asymmetry and make information more comparable. However, the adoption of international accounting and auditing standards is not enough. There are three important links which exist in the enforcement sequence: (a) The top management must ensure preparation of financial statements in compliance with established standards; (b) Auditors must act independently and judiciously to assure the compliance of financial statements with applicable accounting standards and represent a true and fair position of the company ;(c) Regulators must monitor the compliance with accounting standards and take appropriate actions against violators.

Jermakowicz (2004) narrated the challenges on the lack of guidance during the application of IFRS for Belgian publicly traded companies posing the risk of multiples interpretations during the initial IFRS reporting. (Larson \& Street, 2004), stated in their scholarly work that there must a coordinated regulatory review and enforcement system to provide for the stable application. The complexity related to certain IFRSs and tax orientation of most countries have been recognized as the two major significant impediments to convergence

In the opinion of Patro and Gupta, (2012) before introducing IFRS in the accounting curriculum, the teachers must acquire the necessary knowledge, beginning with the basic background knowledge till the trends towards global accounting standards. In order to ensure successful learning, special planning for placing the IFRS modules in the accounting curriculum is required. According to Laga (2013), the obstacles in adoption and implementation of IFRS in Libya are Lack of technical skills and inadequate knowledge of the Libyan professional accountants, Inconsistency of existing laws and regulatory frameworks of accounting in Libya with the recent development of accounting profession, Weakness of Professional accounting body. According to Hossain, Hasan \& Safiuddin, (2015), adoption of IFRS means adopting a complete set of different reporting standards. In Bangladesh, the awareness of these reporting standards is still not there among the stakeholders like Banks, Financial institutions, Stock Exchanges, etc. Creating awareness of these standards is a complex task. Moreover, training material on IFRS is scarce. According s there is a critical need to deal with the challenges of IFRS and work towards its adoption by 
implementing the roadmap in India. The need of the hour is building up adequate IFRS skills and ample knowledge among the accounting professionals who can supervise the conversion process. Street (2004) and UNCTAD (2008) found out in their research that one of the widely documented challenges for IFRS implementation is 'the complicated nature of some IFRS', its voluminous nature and enormous requirements such as standards on financial instruments

\section{Research Methodology}

The literature shows the evidences that in descriptive and exploratory research on any subject or IFRS, the structured (both open and closed ended) questionnaire using five-point Likert is the most suitable technique. Buckingham and Saunders (2004), Foo (2008), Jermakowicz (2004), Joshi et al. (2008), Kanakriyah (2013) and Morris et al. (2013) in their report recognized that questionnaire approach is the most suitable approach for exploratory research. This research recognizes key benefits and challenges associated with the adoption of IFRS in India. The questionnaire was pre tested and well researched to suit the desired research purpose. The sample size for this study was 150 accounting professionals (Chartered Accountants) from various sectors of Indian economy. Both qualitative and quantitative data and information was gathered and applied to obtain the meaningful outcome. This research adopted purposive sampling procedure to suit the research context and assemble meaningful outcome. The questionnaire was developed to solicit the information from target respondents regarding benefits and challenges related to IFRS convergence mechanism in India. The data was assembled through administering a well-designed and structured (both open and closed ended ) questionnaire using five-point Likert scale questions of "1-Strongly Disagree", "2-Disagree", "3-Neutral", "4-Agree" and "5-Strongly Agree"., semantic scale questions, nominal scale questions, and demographic questions. Both descriptive and inferential statistics have been applied to derive the outcome of the research. The research purpose includes finding out the data from respondents regarding benefits and challenges related to the IFRS convergence mechanism in India and explaining them through frequency and percentile table.

\section{Data Analysis}

Since IFRS has been enforced by more than 110 nations and others are planning to shift to this high quality principle based standards, India too is not an exception. India is the most recent participant in the IFRS convergence process where the adoption of the Indian Accounting Standards (Ind-AS) will initiate from the financial year 2016-2017. This research is motivated to explore the issues and challenges faced by the accounting bodies and members of the accounting profession in India in implementing the IFRS-based accounting standards. The present study consists of a total of 150 chartered accountants who was surveyed to find out research answers. Data was collected through a structured five-point likert scale questionnaire and was analyzed by using descriptive statistics frequency and percentile method, etc. Narrative approach has been used to explain open-ended questions. 


\section{Macrothink}

International Journal of Accounting and Financial Reporting

Table 1. Descriptive statistics of the respondents

\begin{tabular}{|c|c|c|c|}
\hline Variable & Sub Value & Frequency & Percent $\%$ \\
\hline \multirow[t]{2}{*}{ Gender } & Male & 86 & 57.33 \\
\hline & Female & 64 & 42.67 \\
\hline Total & & 150 & 100.0 \\
\hline \multirow[t]{4}{*}{ Age } & Blow 30 & 88 & 58.67 \\
\hline & $30-40$ & 58 & 38.67 \\
\hline & $40-50$ & 2 & 1.33 \\
\hline & 50 and Above & 2 & 1.33 \\
\hline Total & & 150 & 100.0 \\
\hline \multirow{3}{*}{$\begin{array}{l}\text { Professional } \\
\text { affiliation }\end{array}$} & Self-Practice & 24 & 16.00 \\
\hline & Employed in Audit Firm & 88 & 58.67 \\
\hline & Corporate Employee & 38 & 25.33 \\
\hline Total & & 150 & 100.0 \\
\hline \multirow{4}{*}{$\begin{array}{l}\text { Area of } \\
\text { specialization } \\
\text { (Roles and Positions) }\end{array}$} & Accounts & 36 & 24.00 \\
\hline & Audit & 76 & 50.67 \\
\hline & Taxation & 34 & 22.67 \\
\hline & Other & 4 & 2.67 \\
\hline Total & & 150 & 100.0 \\
\hline \multirow[t]{4}{*}{ Experience } & Below 5 years & 132 & 88.00 \\
\hline & 5-10 Years & 12 & 8.00 \\
\hline & 10-15 Years & 0.00 & 0.00 \\
\hline & 15 Years and above & 6 & 4.00 \\
\hline Total & & 150 & 100.0 \\
\hline
\end{tabular}

The above table displays the descriptive statistics associated with the demographic details of respondents like age, gender, years of experience, professional affiliation and area of specialization (Roles and Positions). The questionnaire was administered to 150 chartered accountants from all business sectors in India through personal contact. The results given in 
the above table reveal that more than half of the respondents were male i.e. $57.33 \%$ male and $46.67 \%$ female. The majority of the respondents were below 30 age which is around $58.7 \%$ followed by $38.67 \%$ where age is ranging between $30-40$ which demonstrates that majority of the respondents were young accounting professionals. Merely $1.33 \%$ of the respondent's ages were between $40-50$ and $1.33 \%$ was above 50 . As per the results, $16 \%$ were self-employed employees, $58.67 \%$ were working in an audit firm rest 25.33 were corporate employees which shows majority of the respondents were working in Audit firm. The table also explains the area of specialization where $24 \%$ of total respondent were accountants, $50.67 \%$ of total sample size had an area of specialization in auditing, $22.67 \%$ were into taxation and rest $2.67 \%$ had other specialization which indicates that the sample includes auditors in majority. $88 \%$ of respondents were having the experience below 5 years, $8 \%$ had experienced between 5-10 years and the remaining $4 \%$ had experience of 15 years or more. Such demographic analysis is significant as it indicated the extent of knowledge and experience of respondents.

Table 2. Readiness towards IFRS adoption

\begin{tabular}{llllllll}
\hline IFRS Adoption & Yes & & No & & \multicolumn{2}{c}{ Total } \\
\hline & \% & Count & $\%$ & Count & \% & Count \\
\cline { 2 - 7 } & 79 & 118 & 21 & 32 & 100 & 150 \\
1. Are you aware of IFRS? & 71 & 106 & 29 & 44 & 100 & 150 \\
\hline $\begin{array}{l}\text { 2. Is your company/Are you ready to } \\
\text { shift the accounting system/policy from } \\
\text { Indian GAAP to IFRS }\end{array}$ & & & & & & \\
\hline $\begin{array}{l}\text { 3. If yes, Has the process of adoption of } \\
\text { IFRS started in your company? }\end{array}$ & 66 & 70 & 34 & 36 & 71 & 106 \\
\hline
\end{tabular}

The above table explains the target respondent's response towards readiness for IFRS in India. Most of the respondents, approx. 79\%, stated that they are aware about IFRS but when asked in details about which of the accounting rules they are more familiar with, $40 \%$ responded that they understand IndAS followed by $37 \%$ who stated that they are familiar with Indian GAPP. Only 22\% respondents understand IFRS application. Thus overall understanding about IFRS and Ind AS which is IFRS converged accounting standards stands for $63 \%$ in total as explained in figure No. 1 . As per above table only 106 respondent responded that the process had stared other 44 said that they haven't started the process of adoption of IFRS in their company. In addition total $71 \%$ (106) respondents stated that they are ready for the transition from Indian GAAP to IFRS and 66\% (70 out of 106 respondents) confirmed that the process of IFRS adoption has been initiated in their respective organization. Rest 34\% (36 out of 106 respondents) stated that the process has not started yet. 
Others Which of the Following Are You Aware of? $1 \%$

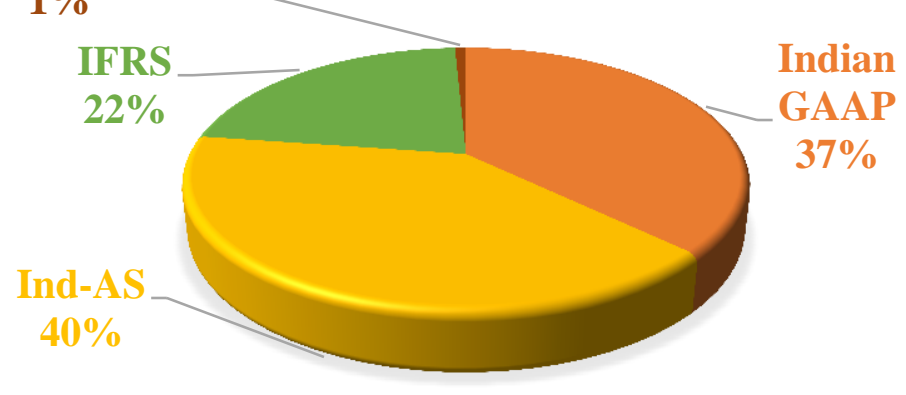

Figure 1. Awareness about IFRS

As per above figure, $40 \%$ were aware about Ind-AS, 37\% were aware about Indian GAAP, $22 \%$ were aware about IFRS and remaining $1 \%$ were aware about U.S GAAP

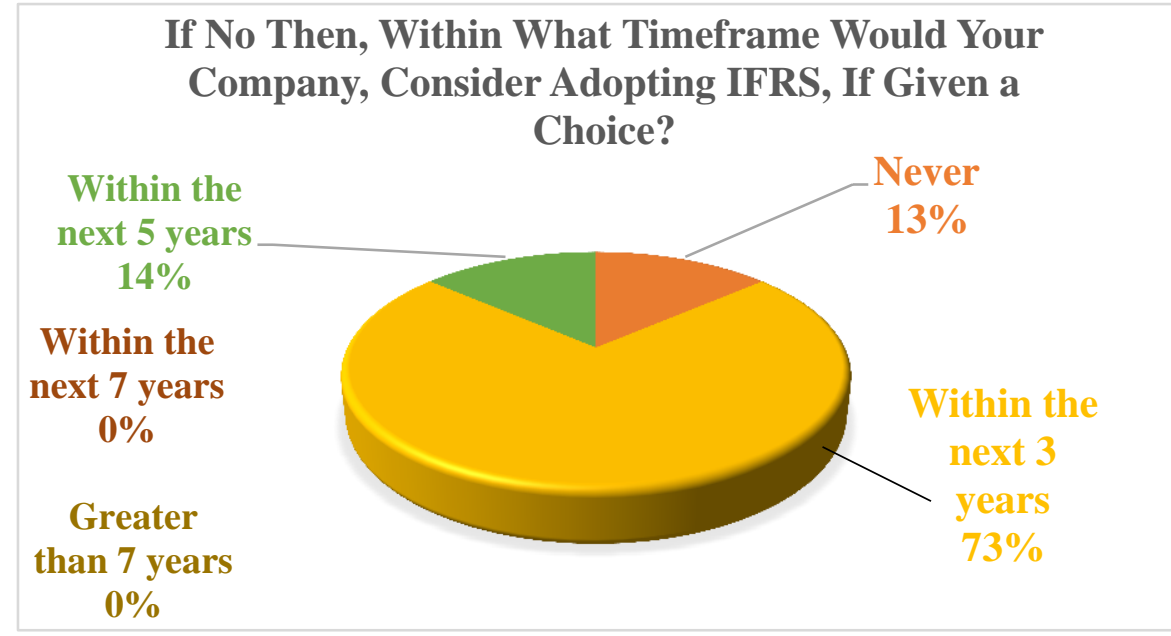

Figure 2. Time Limit for the adoption of IFRS

Out of 44 respondents i.e. 34\% respondent, who are not ready to shift their accounting system or policy from Indian GAAP to IFRS, $73 \%$ would take 3 years to shift, $14 \%$ will take 5 years to shift and $13 \%$ would never shift their accounting system or policy.

Table 3. Reliability statistics (Cronbach's Alpha test)

\begin{tabular}{|c|c|c|c|c|}
\hline Item & Cronbach's Alpha & $\begin{array}{l}\text { Cronbach's Alpha } \\
\text { Standardized Items }\end{array}$ & Based on & $\mathrm{N}$ of Items \\
\hline Benefits & 0.84 & 0.86 & & 10 \\
\hline Challenges & 0.73 & 0.75 & & 7 \\
\hline
\end{tabular}




\section{Mll Macrothink}

International Journal of Accounting and Financial Reporting

ISSN 2162-3082

2019, Vol. 9, No. 4

A test for internal reliability and consistency is measured using Cronbach's Alpha Test and presented in Table 3. This study had 10 standardized items for benefits and 7 standardized items for challenges. Table 3 explained that Cronbach's Alfa was .84 and .73 respectively which is acceptable as per (field, 2009) in social science research. According to (Malhotra and Dash, 2008) Cronbach's Alpha value .6 or more indicates an acceptable level of consistency.

Table 4. Computed variables

\begin{tabular}{lllllll}
\hline Items & Mean & Std. Error & Std. Dev & Variance & kurtosis & Skewness \\
\hline Benefits & 3.966 & 0.066162 & 0.81031 & 0.65996 & 0.554688 & -0.68474 \\
\hline Challenges & 2.723333 & 0.042161 & 0.516371 & 0.387781 & 0.245286 & -0.4036 \\
\hline
\end{tabular}

Table 4 displays the computed variables mean, standards error, standard deviation, variance, kurtosis and Skewness of benefits and challenges. The result in the above table shows the respondent's perspective with the mean of benefit 3.966 and mean of challenges 2.7233 which indicates that benefits of IFRS overweigh the cost and the challenges of IFRS adoption.

Table 5. Benefits of IFRS implementation in India

\begin{tabular}{|c|c|c|c|c|c|c|c|c|c|c|c|c|c|}
\hline Statements & Mean & $\mathrm{SD}$ & 5_SA & $\%$ & 4_A & $\%$ & 3_N & $\%$ & 2_D & $\%$ & 1_SD & $\%$ & $\mathrm{~T}$ \\
\hline $\begin{array}{l}\text { IFRS implementation will provide better information } \\
\text { for decision making }\end{array}$ & 4.25 & .77 & 64 & 42.7 & 64 & 42.7 & 18 & 12 & 4 & 2.7 & 0 & 0 & 150 \\
\hline $\begin{array}{l}\text { IFRS implementation will provide for better inter- } \\
\text { company comparison of financial statement }\end{array}$ & 4.16 & .75 & 50 & 33.3 & 78 & 52 & 20 & 13.3 & 0 & 0 & 2 & 1.3 & 150 \\
\hline $\begin{array}{l}\text { IFRS implementation will help in timely financial } \\
\text { reporting }\end{array}$ & 4.07 & .90 & 54 & 36 & 62 & 41.3 & 26 & 17.3 & 6 & 4 & 2 & 13 & 150 \\
\hline $\begin{array}{l}\text { IFRS implementation will provide for Better access } \\
\text { to international capital market }\end{array}$ & 3.92 & .91 & 42 & 28 & 64 & 42.7 & 38 & 25.3 & 2 & 13 & 4 & 2.7 & 150 \\
\hline $\begin{array}{l}\text { IFRS adoption will provide for ease of using one high } \\
\text { standard and consistent reporting standard }\end{array}$ & 4.17 & .83 & 58 & 38.7 & 66 & 44 & 22 & 14.7 & 12 & 1.3 & 2 & 1.3 & 150 \\
\hline $\begin{array}{l}\text { IFRS implementation will reduce cost of equity and } \\
\text { will improve earning management }\end{array}$ & 3.88 & .82 & 38 & 25.3 & 60 & 40 & 48 & 32 & 4 & 2.7 & 0 & 0 & 150 \\
\hline $\begin{array}{l}\text { IFRS implementation will provide a true and fair } \\
\text { view of financial position }\end{array}$ & 4.19 & .78 & 58 & 38.7 & 66 & 44 & 22 & 14.7 & 4 & 2.7 & 0 & 0 & 150 \\
\hline $\begin{array}{l}\text { IFRS implementation will enhance the accuracy and } \\
\text { reliability of financial statements }\end{array}$ & 4.17 & .72 & 51 & 34 & 77 & 51.3 & 19 & 12.7 & 3 & 2 & 0 & 0 & 150 \\
\hline $\begin{array}{l}\text { IFRS implementation will provide opportunities to } \\
\text { Indian professionals at international level }\end{array}$ & 3.13 & .79 & 1 & .7 & 54 & 36 & 58 & 38.7 & 37 & 24.7 & 0 & 0 & 150 \\
\hline $\begin{array}{l}\text { Use of IFRS will help in prevention of accounting } \\
\text { frauds/manipulation }\end{array}$ & 3.72 & .84 & 22 & 14.7 & 76 & 51 & 43 & 28.7 & 6 & 4 & 3 & 2 & 150 \\
\hline
\end{tabular}

Table 5 explains the benefits of IFRS adoption in India and most of the respondents are of the opinion that the implementation of IFRS in India will increase the quality of financial reporting. Increased quality of financial statement will enhance the information symmetry 


\section{Mll Macrothink}

International Journal of Accounting and Financial Reporting

ISSN 2162-3082

2019, Vol. 9, No. 4

and will reduce the overall cost of capital. Respondent also believed that the implementation of IFRS will enhance the comparability and provide for more transparency in financial reporting. The results of this research are supported by (Lenormand and Touchais, 2009; Barth et al., 2008; Epstein, 2009 and Adam, 2009) as they concluded in their research that adoption of IFRS leads to more transparency and increase the quality of financial reporting. Many respondents perceived that IFRS adoption will provide a better inter-company comparison which will help the investors in decision making. In addition, IFRS intends to provide uniformity, transparency and comparability among financial statements across countries which will bridge the gap between local and international capital market and will facilitate more global capital flow into country. Few respondents were also bit positive that the implementation of IFRS in India will improve the job prospects abroad for Indians. Since IFRS is a global accounting standard, the respondents perceive that it will provide for an easy access to global job market especially in international accounting domain. Some respondents were of the view that IFRS implementation will help in preventing the fraud too since it is a high quality standard. IFRS is a principle based standard where management judgment plays an important role. Thus it is expected that adoption of IFRS will lead to reduce the accounting manipulation and fraud. The belief of respondents that IFRS adoption will provide better capital market success is evidenced in the research outcome by (Faraj and Akbar, 2010), who concluded that the adoption of IFRS in developing countries will assist in providing the access to capital markets internationally.

Table 6. Challenges of IFRS implementation in India

\begin{tabular}{|c|c|c|c|c|c|c|c|c|c|c|c|c|c|}
\hline Statements & Mean & $\mathrm{SD}$ & 5_SA & $\%$ & 4_A & $\%$ & 3_N & $\%$ & 2_D & $\%$ & 1_SD & $\%$ & $\mathrm{~T}$ \\
\hline $\begin{array}{l}\text { Inadequate training facilities at huge cost is a road } \\
\text { block to IFRS }\end{array}$ & 4.03 & .80 & 40 & 26.7 & 82 & 54.7 & 22 & 14.7 & 4 & 2.7 & 2 & 1.3 & 150 \\
\hline $\begin{array}{l}\text { The fair value measurement is highly obstructive the } \\
\text { execution of IFRS }\end{array}$ & 3.91 & .91 & 43 & 28.7 & 63 & 42 & 31 & 20.7 & 13 & 8.7 & 0 & 0 & 150 \\
\hline $\begin{array}{l}\text { IFRS adoption requires major changes in IT } \\
\text { infrastructure }\end{array}$ & 4.12 & .65 & 42 & 28 & 84 & 56 & 24 & 16 & 0 & 0 & 0 & 0 & 150 \\
\hline IFRS adoption requires changes in existing law & 4.15 & .69 & 44 & 29.4 & 88 & 58.7 & 14 & 9.3 & 4 & 2.7 & 0 & 0 & 150 \\
\hline $\begin{array}{l}\text { IFRS adoption requires too much disclosure and } \\
\text { changes in whole accounting process }\end{array}$ & 3.85 & .68 & 21 & 14 & 90 & 60 & 35 & 23.3 & 4 & 2.7 & 0 & 0 & 150 \\
\hline $\begin{array}{l}\text { IFRS itself is complicated, hence it increases the risk } \\
\text { of errors and omissions }\end{array}$ & 3.34 & .81 & 0 & 0 & 82 & 54.6 & 38 & 25.3 & 29 & 19.3 & 1 & 6.7 & 150 \\
\hline $\begin{array}{l}\text { IFRS implementation will increase the burden of } \\
\text { Accountants and auditors due to complexity of } \\
\text { conversion }\end{array}$ & 3.84 & .61 & 14 & 9.3 & 102 & 68 & 30 & 20 & 4 & 2.7 & 0 & 0 & 150 \\
\hline
\end{tabular}

Table 6 expresses the respondent's perception regarding cost and challenges associated with IFRS implementation. The study revealed that $81.7 \%$ of respondents believe that training facility for IFRS is inadequate in India. They indicated that the amount of skill and training required for the implementation of IFRS in India is not enough. Few IFRS are technical and require expertise in that area. Hence respondents think that more professional training is required to impart which involves huge training cost. This result is supported by the conclusion of (Dunne et al., 2008) that draws the inference that IFRS is actually not too cumbersome and not difficult to understand. The majority further responded that fair value 
measurement is highly complicated and since Indian market is not an active market like other developed economy hence it is difficult to determine the price of an asset. Fair value measurement requires expertise knowledge to determine accurate price of asset. Thus there is need for extensive training regarding IFRS. This support the outcome given by Gyasi (2010), Laga (2012) and schachler et al. (2012) that the implementation of IFRS in developing economy will require extensive training for accountants $84 \%$ of respondents indicated that IFRS implementation needs structure needs changes in IT infrastructure. IFRS is high-quality principle-based standards and in many cases, the adoption of IFRS requires changes in existing country law. Most of the respondents were of the opinion that IFRS implementation will enforce major changed in existing accounting rules. IFRS is international set of rules, the adoption of which might require modification in existing law. In India adoption of IFRS may require few amendments in companies Act, IRDA, banking regulation act, income tax act etc. Majority of the respondents also perceived that IFRS implementation will increase the burden of accounting professionals since it is too subjective and required too much disclosure. Certainly the implementation of IFRS will require huge amount of money to be spent on training and building infrastructure but the benefits of IFRS will overweight the cost.

Non Parametric test

Table 7. Kruskal Wallis H-Test for professional affiliation

\begin{tabular}{lllllllll}
\hline Items & Self-Practice & \multicolumn{3}{l}{ Employed in Audit Firms } & Employed in other Firm & $\begin{array}{l}\text { Kruskal Wallis H-Test } \\
\text { (for all three groups) }\end{array}$ \\
\hline & $\begin{array}{l}\text { Mean of } \\
\text { Response }\end{array}$ & Mean Rank & $\begin{array}{l}\text { Mean of } \\
\text { Response }\end{array}$ & Mean Rank & $\begin{array}{l}\text { Mean of } \\
\text { Response }\end{array}$ & Mean Rank & Chi- square & P value \\
\hline Benefits & 3.93 & 61.83 & 4.22 & 83.93 & 3.96 & 64.50 & 8.20 & 0.017 \\
\hline Challenges & 3.65 & 65.46 & 3.89 & 81.28 & 3.72 & 68.46 & 3.89 & 0.143 \\
\hline
\end{tabular}

Table 8. Kruskal Wallis H-Test for Role and position

\begin{tabular}{lllllllllll}
\hline Items & Accountants & \multicolumn{3}{c}{ Auditors } & & Tax officer & & Others & & \multicolumn{2}{c}{$\begin{array}{l}\text { Kruskal Wallis H-Test } \\
\text { (for all four groups) }\end{array}$} \\
\hline & $\begin{array}{l}\text { Mean of } \\
\text { Response }\end{array}$ & $\begin{array}{l}\text { Mean } \\
\text { Rank }\end{array}$ & $\begin{array}{l}\text { Mean of } \\
\text { Response }\end{array}$ & $\begin{array}{l}\text { Mean } \\
\text { Rank }\end{array}$ & $\begin{array}{l}\text { Mean of } \\
\text { Response }\end{array}$ & $\begin{array}{l}\text { Mean } \\
\text { Rank }\end{array}$ & $\begin{array}{l}\text { Mean of } \\
\text { Response }\end{array}$ & $\begin{array}{l}\text { Mean } \\
\text { Rank }\end{array}$ & $\begin{array}{l}\text { Chi- } \\
\text { square }\end{array}$ & P value \\
\hline Benefits & 4.01 & 68.6 & 4.18 & 80.82 & 4.14 & 77.87 & 3.25 & 16 & 9.69 & 0.021 \\
\hline Challenges & 3.70 & 66.61 & 3.88 & 79.55 & 3.85 & 79.34 & 3.25 & 46 & 4.33 & 0.228 \\
\hline
\end{tabular}

A Kruskal- Wallis $\mathrm{H}$ non- parametric test was applied to test statistically if there are significant differences of perception among three groups of the level of professional affiliation and four groups of roles and position. The Kruskal-Wallis test was calculated using mean values of the two variables i.e. benefits and challenges and the results are displayed in Table 7 and Table 8. The results states that both employed in audit firms and employed in other firms agree upon the benefits and challenges associated with IFRS adoption. The table 8 also demonstrates that accountants, auditors, tax officers and others also agree that challenges associated with IFRS are not much and it does not overweighs the benefits. The 
perception regarding the benefits of IFRS are significantly different between the respondents since $\mathrm{P}$ value <.05

\section{Conclusion}

This research assembled the data from chartered accountants regarding their perception about IFRS convergence mechanism in India, a developing country. The conclusion of the study states the perspective of the respondents, majority of whom were auditors working in audit firms were optimistic that the benefits of IFRS adoption are more than the cost and challenges of IFRS adoption in India. Nevertheless, they also concluded that cost associated with transition from Indian GAPP to IFRS is lessor in contrast the benefits provided by enforcement of IFRS. Chen et al. (2010), indicated in their research that the substitution of domestic standards with the IFRS will increase the quality of financial reporting; and the similar outcome was reinstated by Landsman et al. (2012), that the implementation of IFRS will bring benefits in three aspects: improved information content, reduced gap in reporting and will enhance the flow of foreign investment

However, in India, the compliance with FRS will bring various challenges and a potential important critical question is how it will trade off the potential benefits and costs when they consider IFRS adoption or convergence with IFRS. But in nutshell, overall benefits of IFRS still outweighs its challenges with advantages like timely information for decision making, better inter-company comparison of financial statements, better access to capital market, consistent reporting etc. This study conclusion is supported by the results of (Richmell Baaba Amanamah, 2017) who concluded that the benefits of adopting the IFRS outweigh the cost. This research outcome provides valuable insights to Indian accounting professionals and managers on prospective benefits of IFRS convergence and the results are more likely to be significant for both the user and prepares

This study only consists of 150 respondents which may not represent the whole population and included only 10 items of benefits and 7 items of challenges regarding IFRS adoption in India which could have been more. Future researchers can separately analyze the perceptions of users and preparers and they can compare both challenges and benefits across globe. They may take a more diversified sample and large sample size. Future research can be conducted in many other countries regarding benefit and challenges. Value relevance is an aspect of the adoption of IFRS which can be studied as well.

\section{References}

Adam, M. (2009). The Challenges of Adopting International Financial Reporting Standards. Zenith Economic Quarterly, 4(2), 102-116.

Aggarwal, S. (2016), International Financial Reporting Standards: An Indian Perspective: A Road Map. IOSR Journal of Business and Management, 18(1), 01-05.

Amanamah, R. B. (2017). Benefits and Challenges of International Financial Reporting Standards Adoption in Ghana: Accounts and Business Managers Perspective. International Journal of Accounting and Financial Reporting, 7(2), 178-193. 


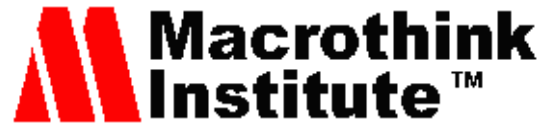

International Journal of Accounting and Financial Reporting

ISSN 2162-3082

Arum Puspa, E. D. (2013). Implementation of IFRS and quality of financial information in Indonesia. The Research Journal of Finance and Accounting, 4(19), 1-7.

Bapna, M. (2003). A Study of IFRS and its Adoption in India - Prospects and Challenges. International Journal of Engineering Technology Science and Research, 4, 1330-334.

Barth, M. E., Landsman, W. R., \& Lang, M. H. (2008). International Accounting Standards and Accounting Quality. Journal of Accounting Research, 46(3), 467-498.

Bhattacharjee, S., \& Islam, M. Z. (2009). Problems of Adoption of International Financial Reporting Standards (IFRS) in Bangladesh. International Journal of Business and Management, 4(12), 165-175.

Buckingham, A., \& Saunders, P. (2004). The Survey Methods Workbook: From Design to Analysis. Cambridge Polity Press, Cambridge.

Chen, J. J., \& Zhang, H. (2010). The impact of regulatory enforcement and audit upon IFRS compliance - evidence from China. European Accounting Review, 19(4), 665-692.

Choi, F., \& Levich, R. (1991, July/August). International Accounting Diversity: Does it Affect Market Participants?. Financial Analysts Journal, 73-82.

Dunne, T., Fifield, S., Finningham, G., Fox, A., Hannah, G., Helliar, C., Power, D., \& Veneziani, M. (2008). The implementation of IFRS in the UK, Italy, and Ireland. The Institute of Chartered Accountants of Scotland.

Epstein, B. J. (2009). The Economic Effect of IFRS Adoption. CPA Journal, 3, 26-31.

Evans, O. N. D., \& Ocansey, J. A. E. (2014). Comparative Study of the International Financial Reporting Standard Implementation in Ghana and Nigeria. European Scientific Journal, 10(13).

Ezeani, N. S., \& Oladele, R. (2012). Adoption of international financial reporting standards (IFRS) to enhance financial reporting. Arabian Journal of Business and Management Review, 2(3), 10-16.

Faraj, S., \& Akbar, S. (2010). An Empirical Investigation of The Libyan Audit Market: Perceptions of Auditor's Independence. Journal for Global Business Advancement, 3(2), 133-154.

Forsberg, J., \& Ojala. (2014). Adoption of IFRS in the Chinese accounting standards.

Gyasi, A. (2010). Adoption of International Financial Reporting Standards in Developing Countries - The Case of Ghana. BSc Dissertation, University of Applied Sciences.

Hassan, O. A. G., Romilly, P., Giorgioni, G., \& Power, D. (2009). The value relevance of disclosure: Evidence from the emerging capital market of Egypt. The International Journal of Accounting, 44, 79-102. 


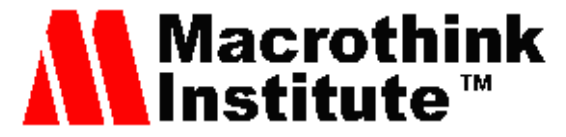

International Journal of Accounting and Financial Reporting

ISSN 2162-3082

2019, Vol. 9, No. 4

Hossain, M., Hasan, M., \& Safiuddin, M. (2015). Adoption of International Financial Reporting Standards in Bangladesh: Benefits and challenges. IOSR Journal of Business and Management, 17(8), 16-24.

Hoyle, B., Schaefer, E., \& Doupnik, S. (2009). Advanced Accounting (9th ed.). McGraw Hill

Iatridis, G., \& Rouvolis, S. (2010). The post-adoption effects of the implementation of International Financial Reporting Standards in Greece. Journal of International Accounting, Auditing, and Taxation, 19(1), 55-65.

Irvine, H., \& Lucas, N. (2006). The Globalization of Accounting Standards: The case of the United Arab Emirates. Working paper of 3rd International Conference on Contemporary Business, Charles Sturt University, Australia.

Jermakowicz, E. K. (2004). Effects of adoption of International financial reporting standards in Belgium: the evidence from BEL-20 companies. Accounting in Europe, 1(1), 51-70.

Jermakowicz, E. K., \& Gornik-Tomaszewski, S. (2006). Implementing IFRS from the perspective of EU publicly traded companies. Journal of International Accounting, Auditing and Taxation, 15(2), 170-196.

Jones, S., \& Higgins, A. D. (2006). Australia's switch to international financial reporting standards: a perspective from account preparers. Accounting and Finance, 46(4), 629-652.

Joshi, P., Bremser, W. G., \& Al-Ajmi, J. (2008). Perceptions of accounting professionals in the adoption and implementation of a single set of global accounting standards: evidence from Bahrain. Advances in Accounting, 24(1), 41-48.

Kanakriyah, R. (2013). The effect of asset impairment (IAS 36) in improving the quality of accounting information according to users' perspective: evidence from Jordan. PhD Thesis, Durham University, Durham

Laga, M. (2012). Obstacles of Adopting and implementation of IFRS in Libya. European Journal of Business and Economics, 7, 1-3,

Landsman, W. R., Maydewa, E. L., \& Thornock, J. R. (2012). The information content of annual earnings announcements and mandatory adoption of IFRS. Journal of Accounting and Economics, 53(1), 34-54.

Latifah, I., Asfadillah, C., \& Sukmana, R. (2012). History and Development of IFRS and AAOIFI and Their Future Challenge. Working paper of Cambridge Business, and Economics Conference, Cambridge University, UK.

Lenormand, G., \& Touchais, L. (2009). Do IFRS improve the quality of financial information? A value relevance approach. Comptabilité - Contrôle. Audit, 15(2), 145-164.

Madawaki, A. (2012). Adoption of international financial reporting standards in developing countries: The case of Nigeria. International Journal of Business and Management, 7(3), 152-161. 


\section{I Macrothink}

International Journal of Accounting and Financial Reporting ISSN 2162-3082 2019, Vol. 9, No. 4

Malhotra, N. K. (2008). Marketing research: An applied orientation (5th ed.). Pearson Education India.

Miazee, H. (2014). Problems of Implementing of International Financial Reporting Standards in Bangladesh. European Journal of Business and Management, 6, 81-174.

Morris, R. D., Gray, S. J., Pickering, J., \& Aisbitt, S. (2013). Preparers' perceptions of the costs and benefits of IFRS: evidence from Australia's implementation experience. Accounting Horizons, 28(1), 143-173.

Naghshbandi, N., Ombati, R., \& Khosravi, V. (2016). Empirical study of the impact of culture on accounting practices: does it disappear after the introduction IFRS?. International Journal for Research in Business, Management, and Accounting, 2(3), 108-120.

Nobes, C. W., \& Parker, R. (2006). Comparative International Accounting. Prentice-Hall, London.

Nwabueze, A. A (2012). Adoption of IFRS and global capital market integration. International Journal of Research in Commerce and Management, 3(2), 36-44.

Ocheni, S. (2015). Percieved challenges of international financial reporting standards (IFRS) adoption in Nigeria. Indian Journal of Commerce and Management Studies, 6(1), 7-16.

Paglietti, P. (2009). Earnings management, timely loss recognition and value relevance in Europe following mandatory adoption: evidence from Italian listed companies. Economia Aziendale, 4, 97-117.

Panama, M., \& Lin, H. (2009). The Development of Accounting Quality of IAS and IFRS over Time: The case of Germany. Journal of International Accounting Research, 8(1), 31-55.

Patro, A., \& Gupta, V. K. (2012). Adoption of International Financial Reporting Standards (IFRS) in Accounting Curriculum in India - An Empirical Study. Procedia Economics and Finance, 2, 227-236.

Quigley, J. (2007). Deloitte \& Touche World Meeting, Berlin Germany SEC - IFRS - Global financial reporting standards. Retrieved from http://www.deloitte.com

Rao, S., \& Malyadri, P. (2015). International Financial Reporting Standards: A-Frame Work. Journal of Accounting \& Marketing, 4(2), 1-4.

Ratheesh, R. J., \& Anjula, C. S. (2015). IFRS in Indian Context. International Journal of Management and Commerce Innovations, 3(1), 149-153.

Schachler, M., Al-Abiyad, S., \& Al-Hadad, A. (2012). Evaluation of the Suitability of International Financial Reporting Standards (IFRSs) for Application in Emerging North African Countries: A Literature Review and a Research Agenda. Journal of Modern Accounting and Auditing, 8(12), 1773-1779. 


\section{1) Macrothink}

International Journal of Accounting and Financial Reporting

ISSN 2162-3082

2019, Vol. 9, No. 4

Street, D. L., \& Larson, R. K. (2004). Large accounting firms' survey reveals the emergence of the "Two Standard" system in the European Union. Advances in International Accounting, 17.

UNCTAD. (2008). International Accounting and Reporting Issues (pp. 2-74). United Nations.

Venkatesh, D., \& Venkateswarlu, M. (2016). Opportunities and Challenges in Adopting IFRS in India. National Seminar on "IND-AS: A Road Map for IFRS in India" (pp. 1-6).

Vinayaga, M. A. (2016). IFRS and Indian current scenario. International Journal of Scientific Research \& Education, 2(4), 753-760.

Weaver, L., \& Woods, M. (2015). The challenges faced by reporting entities on their transition to International Financial Reporting Standards: a qualitative study. Accounting in Europe, 12(2), 1-25.

Whittington, G. (2008). Harmonisation or discord? The critical role of the IASB conceptual framework review. Journal of Accounting and Public Policy, 27(6), 495-502.

Zeghal, D., \& Mhedhbi, K. (2006). An analysis of the factors affecting the adoption of international accounting standards by developing countries. The International Journal of Accounting, 4(1), 373-386.

\section{Copyright Disclaimer}

Copyright for this article is retained by the author(s), with first publication rights granted to the journal.

This is an open-access article distributed under the terms and conditions of the Creative Commons Attribution license (http://creativecommons.org/licenses/by/4.0/) 